\title{
Front Matter: Volume 7551
}

, "Front Matter: Volume 7551," Proc. SPIE 7551, Optical Methods for Tumor Treatment and Detection: Mechanisms and Techniques in Photodynamic Therapy XIX, 755101 (31 March 2010); doi: 10.1117/12.861261

SPIE. Event: SPIE BiOS, 2010, San Francisco, California, United States 


\section{PROGRESS IN BIOMEDICAL OPTICS AND IMAGING}

Vol. 11, No. 4

\section{Optical Methods for Tumor Treatment and Detection: Mechanisms and Techniques in Photodynamic Therapy XIX}

David H. Kessel

Editor

23-25 January 2010

San Francisco, California, United States

Sponsored and Published by

SPIE

Volume 7551

Proceedings of SPIE, 1605-7422, v. 7551

SPIE is an international society advancing an interdisciplinary approach to the science and application of light. 
The papers included in this volume were part of the technical conference cited on the cover and title page. Papers were selected and subject to review by the editors and conference program committee. Some conference presentations may not be available for publication. The papers published in these proceedings reflect the work and thoughts of the authors and are published herein as submitted. The publisher is not responsible for the validity of the information or for any outcomes resulting from reliance thereon.

Please use the following format to cite material from this book:

Author(s), "Title of Paper," in Optical Methods for Tumor Treatment and Detection: Mechanisms and Techniques in Photodynamic Therapy XIX, edited by David H. Kessel, Proceedings of SPIE Vol. 7551 (SPIE, Bellingham, WA, 2010) Article CID Number.

ISSN 1605-7422

ISBN 9780819479471

Published by

SPIE

P.O. Box 10, Bellingham, Washington $98227-0010$ USA

Telephone +1 3606763290 (Pacific Time) · Fax +1 3606471445

SPIE.org

Copyright (C) 2010, Society of Photo-Optical Instrumentation Engineers.

Copying of material in this book for internal or personal use, or for the internal or personal use of specific clients, beyond the fair use provisions granted by the U.S. Copyright Law is authorized by SPIE subject to payment of copying fees. The Transactional Reporting Service base fee for this volume is $\$ 18.00$ per article (or portion thereof), which should be paid directly to the Copyright Clearance Center (CCC), 222 Rosewood Drive, Danvers, MA 01923. Payment may also be made electronically through CCC Online at copyright.com. Other copying for republication, resale, advertising or promotion, or any form of systematic or multiple reproduction of any material in this book is prohibited except with permission in writing from the publisher. The CCC fee code is $1605-7422 / 10 / \$ 18.00$.

Printed in the United States of America.

Publication of record for individual papers is online in the SPIE Digital Library.

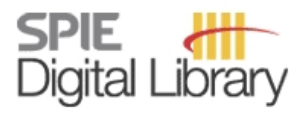

SPIEDigitallibrary.org

Paper Numbering: Proceedings of SPIE follow an e-First publication model, with papers published first online and then in print and on CD-ROM. Papers are published as they are submitted and meet publication criteria. A unique, consistent, permanent citation identifier (CID) number is assigned to each article at the time of the first publication. Utilization of CIDs allows articles to be fully citable as soon they are published online, and connects the same identifier to all online, print, and electronic versions of the publication. SPIE uses a six-digit CID article numbering system in which:

- The first four digits correspond to the SPIE volume number.

- The last two digits indicate publication order within the volume using a Base 36 numbering system employing both numerals and letters. These two-number sets start with 00, 01, 02, 03, 04, 05, 06, 07, 08, $09,0 A, O B \ldots 0 Z$, followed by 10-1Z, 20-2Z, etc.

The CID number appears on each page of the manuscript. The complete citation is used on the first page, and an abbreviated version on subsequent pages. Numbers in the index correspond to the last two digits of the six-digit CID number. 


\section{Contents}

vii Conference Committee

\section{PDT SESSION 1}

755102 Effects of PDT on the endocytic pathway [7551-01]

D. Kessel, Wayne State Univ. (United States)

755103 Molecular factors in cell (and tumor) response to photodynamic therapy: the role of Bid [7551-02]

S. Chiv, L. Xue, Case Western Reserve Univ. (United States); M. Lam, Case Western Reserve Univ. (United States) and Case Comprehensive Cancer Ctr., Case Western Reserve Univ. (United States); M. E. Rodriguez, P. Zhang, Case Western Reserve Univ. (United States);

M. E. Kenney, Case Western Reserve Univ. (United States) and Case Comprehensive Cancer Ctr., Case Western Reserve Univ. (United States); A.-L. Nieminen, Medical Univ. of South Carolina (United States) and Hollings Cancer Ctr., Medical Univ. of South Carolina (United States); N. L. Oleinick, Case Western Reserve Univ. (United States) and Case Comprehensive Cancer Ctr., Case Western Reserve Univ. (United States)

755104 Theranostic nanocells for simultaneous imaging and photodynamic therapy of pancreatic cancer [7551-03]

B. Spring, Z. Mai, P. Rai, S. Chang, T. Hasan, Wellman Ctr. for Photomedicine, Massachusetts General Hospital (United States)

\section{PDT SESSION 2}

755105 Vitamin D as a potential enhancer of aminolevulinate-based photodynamic therapy for nonmelanoma skin cancer (Invited Paper) [7551-04]

E. V. Maytin, S. Anand, N. Atanaskova, C. Wilson, Cleveland Clinic Lerner Research Institute (United States)

755106 In vivo detection of time-resolved singlet oxygen luminescence under PDT relevant conditions [7551-05]

J. Schlothauer, B. Röder, S. Hackbarth, Humboldt-Univ. zu Berlin (Germany); J. Lademann, Charité Universitätsmedizin Berlin (Germany)

755109 Spectroscopic evaluation of photodynamic therapy of the intraperitoneal cavity [7551-08] J. C. Finlay, J. L. Sandell, T. C. Zhu, R. Lewis, K. A. Cengel, S. M. Hahn, Univ. of Pennsylvania (United States)

\section{PDT SESSION 3}

$7551 \mathrm{OB}$ A fast heterogeneous algorithm for light fluence rate for prostate photodynamic therapy [7551-10]

C. Chang, K. K.-H. Wang, T. C. Zhu, Univ. of Pennsylvania School of Medicine (United States) 
7551 OC A treatment planning system for pleural PDT [7551-11]

J. Sandell, C. Chang, J. C. Finlay, T. C. Zhu, Univ. of Pennsylvania School of Medicine (United States)

$7551 \mathrm{OE} \quad$ A heterogeneous optimization algorithm for reacted singlet oxygen for interstitial PDT [7551-13]

T. C. Zhu, M. D. Altschuler, Y. Hu, K. Wang, J. C. Finlay, A. Dimofte, K. Cengel, S. M. Hahn, Univ. of Pennsylvania School of Medicine (United States)

7551 OF In vivo PDT dosimetry: singlet oxygen emission and photosensitizer fluorescence [7551-14] S. Lee, K. L. Galbally-Kinney, B. A. Murphy, S. J. Davis, Physical Sciences Inc. (United States); T. Hasan, B. Spring, Y. Tu, Wellman Ctr. for Photomedicine, Massachusetts General Hospital (United States); B. W. Pogue, M. E. Isabelle, J. A. O'Hara, Dartmouth-Hitchcock Medical Ctr. (United States)

\section{PDT SESSION 4}

7551 OG Targeting cytochrome C oxidase in mitochondria with Pt(II)-porphyrins for photodynamic therapy [7551-15]

M. Börsch, Univ. Stuttgart (Germany)

7551 Ol Three-dimensional ovarian cancer models: imaging and therapeutic combinations [7551-17]

J. P. Celli, Wellman Ctr. for Photomedicine, Massachusetts General Hospital, Harvard Medical School (United States); I. Rizvi, Wellman Ctr. for Photomedicine, Massachusetts General Hospital, Harvard Medical School (United States) and Dartmouth College (United States); C. L. Evans, A. Abu-Yousif, T. Hasan, Wellman Ctr. for Photomedicine, Massachusetts General Hospital, Harvard Medical School (United States)

7551 0J Visualizing photodynamic therapy response with time-lapse OCT in an in vitro model of metastatic ovarian cancer [7551-18]

C. L. Evans, Wellman Ctr. for Photomedicine, Massachusetts General Hospital, Harvard Medical School (United States); I. Rizvi, Wellman Ctr. for Photomedicine, Massachusetts General Hospital, Harvard Medical School (United States) and Dartmouth College (United States); J. Celli, A. Abu-Yousif, Wellman Ctr. for Photomedicine, Massachusetts General Hospital, Harvard Medical School (United States); J. de Boer, Vrije Univ. Amsterdam (Netherlands); T. Hasan, Wellman Ctr. for Photomedicine, Massachusetts General Hospital, Harvard Medical School (United States)

\section{PDT SESSION 5}

7551 OL Photodynamic therapy for locally advanced pancreatic cancer: early clinical results [7551-20]

N. S. Sandanayake, M. T. Huggett, Univ. College London (United Kingdom); S. G. Bown, National Medical Laser Ctr., Univ. College London (United Kingdom); B. W. Pogue, Dartmouth College (United States); T. Hasan, Wellman Ctr. for Photomedicine, Massachusetts General Hospital (United States); S. P. Pereira, Univ. College London (United Kingdom) 
7551 OP Preliminary study of optical properties of hematoporphyrin monomethyl ether (HMME), a new PDT sensitizer [7551-24]

G. F. Glazner, T. C. Lei, L. Scherrer, S. Pendyala, M. Duffy, Univ. of Colorado, Denver (United States); X. Wang, H. Wang, Shanghai Skin Diseases and STD Hospital (China); F. W. Hetzel, Z. Huang, Univ. of Colorado, Denver (United States)

$75510 Q \quad$ EGF targeted fluorescence molecular tomography as a predictor of PDT outcomes in pancreas cancer models [7551-25]

K. S. Samkoe, S. C. Davis, S. Srinivasan, M. E. Isabelle, J. O'Hara, Dartmouth College (United States); T. Hasan, Wellman Ctr. for Photomedicine, Massachusetts General Hospital (United States); B. W. Pogue, Dartmouth College (United States)

7551 OR Novel visible light activated type 1 photosensitizers [7551-26]

R. Rajagopalan, A. Karwa, A. R. Poreddy, P. M. Lusiak, R. S. Pandurangi, G. L. Cantrell,

R. B. Dorshow, Covidien Pharmaceuticals (United States)

\section{PDT SESSION 7}

7551 OS In vitro biological effects of novel type I photosensitizers and their mechanism of action [7551-27]

A. Karwa, R. Rajagopalan, A. R. Poreddy, C. Sympson, G. L. Cantrell, R. B. Dorshow, Covidien Pharmaceuticals (United States)

7551 OT Noninvasive assessment of tissue distribution and tumor pharmacokinetics of Pc 181, a silicon phthalocyanine analogue, in mice [7551-28]

L. Bai, J. Guo, D. M. Clausen, J. L. Eiseman, Univ. of Pittsburgh School of Medicine (United

States) and Univ. of Pittsburgh Cancer Institute (United States)

7551 OV In vivo photodynamic inactivation of Psuedomonas aeruginosa in burned skin in rats [7551-30]

A. Hirao, Keio Univ. (Japan); S. Sato, National Defense Medical College Research Institute (Japan); M. Terakawa, Keio Univ. (Japan); D. Saitoh, National Defense Medical College Research Institute (Japan); N. Shinomiya, National Defense Medical College (Japan); H. Ashida, National Defense Medical College Research Institute (Japan); M. Obara, Keio Univ. (Japan)

7551 OW Patient specific integrating spheres for the improvement of dosimetry in skin PDT [7551-31] D. L. Glennie, McMaster Univ. (Canada); T. J. Farrell, J. E. Hayward, M. S. Patterson, McMaster Univ. (Canada) and Juravinski Cancer Ctr. (Canada); G. Sawesky, Juravinski Cancer Ctr. (Canada)

\section{POSTER SESSION}

755112 Pre-clinic study of uniformity of light blanket for intraoperative photodynamic therapy [7551-37]

Y. Hu, K. Wang, T. C. Zhu, Univ. of Pennsylvania (United States) 
755114 Dependence of light fluence on treated depth with photosensitization reaction shortly after photosensitizer injection in rabbit myocardial tissue in vivo [7551-40]

T. Suenari, H. Matsuo, A. Ito, Keio Univ. (Japan); S. Miyoshi, Keio Univ. School of Medicine (Japan); T. Arai, Keio Univ. (Japan)

755115 In vivo light dosimetry for HPPH-mediated pleural PDT [7551-43]

A. Dimofte, T. C. Zhu, J. C. Finlay, M. Cullighan, C. E. Edmonds, J. S. Friedberg, K. Cengel,

S. M. Hahn, Univ. of Pennsylvania (United States)

755116 In vivo sampling of Verteporfin uptake in pancreas cancer xenograft models: comparison of surface, oral, and interstitial measurements [7551-44]

M. Isabelle, J. A. O'Hara, K. S. Samkoe, Dartmouth College (United States); P. J. Hoopes, Dartmouth College (United States) and Dartmouth Medical School (United States); S. Mosse, S. Pereira, National Medical Laser Ctr., Univ. College London (United Kingdom); T. Hasan, Wellman Ctr. for Photomedicine, Massachusetts General Hospital (United States):

B. W. Pogue, Dartmouth College (United States) and Wellman Ctr. for Photomedicine, Massachusetts General Hospital (United States)

755117 Analytic modeling of antibody versus nanocell delivery of photosensitizer [7551-45] B. W. Pogue, Dartmouth College (United States) and Wellman Ctr. for Photomedicine, Massachusetts General Hospital (United States); S. Srinivasan, K. Samkoe, Dartmouth College (United States); L. Z. Zheng, P. Rai, Z. Mai, S. Verma, T. Hasan, Wellman Ctr. for Photomedicine, Massachusetts General Hospital (United States)

755118 Topical chlorophyll-pheophytin derivative-mediated photodynamic therapy for DMBA-induced hamster buccal pouch premaligant lesions: an in vivo study [7551-46] Y.-C. Hsu, Chung Yuan Christian Univ. (Taiwan); C.-P. Chiang, National Taiwan Univ. (Taiwan); J. W. Chen, Chung Yuan Christian Univ. (Taiwan); J.-W. Lee, Tzu Chi Univ. (Taiwan); M.-H. How, Chung Yuan Christian Univ. (Taiwan)

Author Index 


\title{
Conference Committee
}

\author{
Symposium Chairs \\ James G. Fujimoto, Massachusetts Institute of Technology \\ (United States) \\ R. Rox Anderson, Wellman Center for Photomedicine, Massachusetts \\ General Hospital (United States) and Harvard School of Medicine \\ (United States)
}

Program Track Chair

Reza S. Malek, Mayo Clinic (United States)

Conference Chair

David H. Kessel, Wayne State University (United States)

Conference Cochair

Tayyaba Hasan, Wellman Center for Photomedicine, Massachusetts General Hospital (United States) and Harvard Medical School (United States)

Program Committee

Thomas H. Foster, University of Rochester Medical Center (United States)

Charles J. Gomer, Childrens Hospital Los Angeles (United States)

Nancy L. Oleinick, Case Western Reserve University (United States)

Brian W. Pogue, Dartmouth College (United States)

Kenneth K. Wang, Mayo Clinic (United States)

\section{Session Chairs}

1 PDT Session 1

David H. Kessel, Wayne State University (United States)

2 PDT Session 2

Tayyaba Hasan, Wellman Center for Photomedicine, Massachusetts General Hospital (United States) and Harvard Medical School (United States) 
3 PDT Session 3

Conor L. Evans, Wellman Center for Photomedicine, Massachusetts General Hospital (United States)

4 PDT Session 4

Theresa M. Busch, The University of Pennsylvania Health System (United States)

5 PDT Session 5

Kenneth K. Wang, Mayo Clinic (United States)

6 PDT Session 6

Brian W. Pogue, Dartmouth College (United States)

$7 \quad$ PDT Session 7

Jarod C. Finlay, University of Pennsylvania (United States) 